\title{
Examine The Constitutionality Of Regulations Under Laws That Are Not Contrary To The Law But Contrary To The Constitution
}

\author{
Aditya Yuli Sulistyawan* \& I Putu Eka Cakra \\ Fakultas Hukum Universitas Diponegoro, Semarang \\ adityayuli38@gmail.com
}

\begin{abstract}
Abstrak
Kewenangan untuk memeriksa UU terhadap Konstitusi dilakukan oleh Mahkamah Konstitusi dan pengujian hukum dan peraturan berdasarkan Undang-Undang tentang Hukum dilaksanakan oleh Mahkamah Agung sebagaimana diatur dalam Pasal 24 A paragraf 1 dan 24 C paragraf 1 Undang-Undang Dasar Negara Republik Indonesia Tahun 1945. Namun, dalam perumusan pasal a quo ternyata masih menyisakan masalah, yaitu belum mengatur mekanisme pengujian norma yang terkandung dalam undangundang di bawah undang-undang jika ternyata tidak bertentangan dengan undangundang tetapi bertentangan dengan konstitusi. Tulisan ini membahas pengujian normanorma undang-undang melalui Undang-Undang Dasar Negara Republik Indonesia Tahun 1945 tentang kewenangan peradilan di casu a quo pasal $24 \mathrm{~A}$ ayat 1 dan $24 \mathrm{C}$ ayat 1 Undang-Undang Dasar Negara Republik Indonesia Tahun 1945.
\end{abstract}

Kata kunci: otoritas, hukum, konstitusi.

\begin{abstract}
The authority to examine the Law against the Constitution is carried out by the Constitutional Court and the testing of the laws and regulations under the Law on the Law is carried out by the Supreme Court as regulated in article 24 A paragraph 1 and 24 C paragraph 1 of the 1945 Constitution of the Republic of Indonesia. However, in the formulation of the article a quo it turns out still leaves a problem, namely not yet regulating the norm testing mechanism contained in the legislation under the legislation if it turns out it is not contrary to the law but contrary to the constitution. This paper analyzes the testing of the norms of the legislation through the 1945 Constitution of the Republic of Indonesia Republic IX concerning judicial authority in casu a quo article 24 A paragraph 1 and 24 C paragraph 1 of the 1945 Constitution of the Republic of Indonesia.
\end{abstract}

Keyword: authority, law, the constitution. 


\section{A. Introduction}

Indonesia is a country based on law, and not based on mere power. These provisions are contained in Article 1 Paragraph 3 of the 1945 Constitution of the Republic of Indonesia. The logical consequence of these provisions is that everything in this country is regulated based on legal and statutory provisions. As a country regulated by law, Indonesia also adheres to constitutionalism. This understanding is closely related to the state that is governed by law and makes the constitution as the highest law. Almost all countries in the world have the highest rules on which to run their respective countries. The highest rule is usually called the constitution. Most of the existence of a country's constitution begins with the practice of unlimited authority from a country's leadership. ${ }^{1}$ When a leader of the country acts arbitrarily, the people of that country then rebel and try to limit the arbitrary power. Efforts to limit the power of the authorities are then outlined in a text called the constitution.

The constitution or what is often referred to as the constitution has a meaning according to K.C Wheare as quoted by Bagir Manan and Susi Dwi Harijanti is: first, in the broad sense the constitution is used to describe the whole system of government of a country, a collection of rules that shape and regulate government. There are rules that are legal in the sense that the court recognizes and applies these rules; secondly, in the strict sense, the constitution is a collection of rules governing the state contained in a document. ${ }^{2}$ Every country that places the constitution as the highest law means that it adopts constitutionalism.

Based on the idea of constitutionalism, every time reading the provisions in the Constitution must be interpreted as a limitation of power. ${ }^{3}$ Power is limited by a set of rules that are binding on both the ruler and the people who are bound to the constitution as the highest law. The term constitutionalism means that the powers of government and

\footnotetext{
1 M. Yassin Al-Arif, "Aktualisasi Paham Konstitusionalisme dalam Konstitusi Pasca Amandemen Undang Undang Dasar 1945”, Jurnal Pandecta, Vol. 12 No. 2, 2017, p. 174.

${ }^{2}$ Bagir Manan dan Susi Dwi Harijanti, Memahami Konstitusi Makna dan Aktualisasi, cet 1, (Jakarta, PT RajaGrafindo Persada, 2014), p.10.

${ }^{3}$ Budiman N.PD. Sinaga dan Sahat H.M.T Sinaga, "Syarat Partai Politik Peserta Pemilihan Umum yang Inkonstitusional”, Jurnal Masalah-Masalah Hukum, Jilid 48. No. 3 Juli 2019, p. 253
} 
leaders are limited and these restrictions can be enforced through the establishment of procedures. As a doctrine of political and legal institutions, this refers to the government which was originally devoted both to the good of the whole society and to protecting one's individual rights. ${ }^{4}$

However, there are problems in the legislative hierarchy system in Indonesia, namely the mechanism for testing the constitutionality of laws and regulations under laws that are not contrary to laws but are contrary to the constitution. The problem is in the mechanism of testing the norms of laws and regulations under the laws that conflict with the constitution, whether it is the authority of the Supreme Court or the Constitutional Court, because so far such testing mechanisms have not been regulated.

Based on the provisions in Article 24 A Paragraph 1 of the 1945 Constitution of the Republic of Indonesia, it is regulated that the Supreme Court has the authority to adjudicate at the cassation level, examine the statutory provisions under the law against the law, and have other powers granted by law. Whereas the authority of the Constitutional Court is regulated in Article $24 \mathrm{C}$ Paragraph 1 which regulates that the Constitutional Court has the authority to adjudicate at the first and last level the decision is final to examine the law against the Constitution, to decide on disputes over the authority of state institutions whose authority is granted by The Constitution, decides the dissolution of political parties, and resolves disputes over election results. ${ }^{5}$

This provision then becomes a gap if there are laws and regulations under the law which are in fact contrary to the constitution, because the 1945 Constitution of the Republic of Indonesia in casu a quo Article 24 A and Article $24 \mathrm{C}$ concerning the authority of the Supreme Court and the Constitutional Court did not regulate the testing mechanism at all. the. The non-regulation of this provision certainly hinders the embodiment of the Indonesian state as a state of law and guarantor of human rights, because without the provisions of the norm testing, it is not impossible that there will be constitutional rights of citizens who have the potential to be violated.

\footnotetext{
${ }^{4}$ Ibid, p. 177.

${ }^{5}$ See more in the provisions of the 1945 Constitution of the Republic of Indonesia Chapter IX concerning Judicial Authority, Article 24 A Paragraph 1 and Article 24 C of the 1945 Constitution of the Republic of Indonesia concerning Judicial Authority.
} 
In this article, the writer focuses his study on the problems studied, namely: what is the mechanism for examining laws and regulations that are not contrary to the law but against the constitution?; and what will be achieved through the mechanism of testing the statutory provisions under the law against the constitution?

\section{B. Discussion}

As a constitutional state that embraces constitutionalism which places the constitution as the highest law. Constitutionalism has been widely recognized as a prerequisite for both democracy and the rule of law because it is based on three elements of agreement, namely: ${ }^{6}$ a). Agreement on common goals or goals (the general goals of society or general acceptance of the philosophy of government); b). Agreement on the rule of law as the basis of government or state administration (the basis of the govenment); and c). Agreement on the form of institutions and constitutional procedures (the form of institutions and procedures).

Indonesia places the constitution as its highest law. As a country that places the constitution as the highest law, the constitution has a dual position, namely as the highest law and also as the basic law. The constitution as the highest law means that all existing legal rules must refer to the provisions contained in the constitution, while the constitution as the basic law means the constitution is the basis for the rule of law that is hierarchically under the constitution.

Henc van Maarseven as quoted by I Dewa Gede Atmadja said that the material elements of the constitutional content can be classified as: ${ }^{7}$ (1) the constitution contains the basic laws of the state; (2) the constitution contains a set of basic rules which establish high state institutions; (3) the constitution contains very important rules about state institutions regarding their power and functional relations; (4) the constitution regulates the human rights and obligations of citizens and the government; (5) the constitution regulates and limits the power of the state and its institutions; (6) the

\footnotetext{
${ }^{6}$ I Dewa Gede Palguna, Pengaduan Konstitusional (Constitutional Complaint) Upaya Hukum terhadap Pelanggaran Hak-Hak Konstitusional Warga Negara, (Jakarta, Sinar Grafika, 2013), p. 30.

${ }^{7}$ I Dewa Gede Atmadja, Hukum Konstitusi Problematika Konstitusi Indonesia Sesudah Perubahan UUD 1945 Edisi Revisi, (Malang, Setara Press, 2009), p. 73.
} 
constitution implicitly contains the ideology of the ruling elite; and (7) the constitution also regulates the material relations between the state and society.

The logical consequence of the above explanation is that the constitution as the highest law as well as the basic law must be further elaborated through the rules of the law underneath. This is consistent with Hans Kelsen's theory in his pure legal theory or known as stufenbau theorie that a legal norm must originate from a higher legal norm, whereas a higher legal norm must be sourced from a higher legal norm and so on so as to stem from the constitution. This theory was then continued by his student, Hans Nawianski who compiled the order of the laws and regulations which when adapted to Indonesia were as follows: ${ }^{8}$ 1). Staatsfundamentalnorm: Pancasila (Opening of the 1945 Constitution of the Republic of Indonesia); 2). Staatsgrundgesetz: Articles of the 1945 NRI Constitution; 3). Formal gezets: Law, and 4). Verordnung en autonome satzung: Hierarchically from government regulations to the decision of the Regent or Mayor.

Based on the elaboration of the theory, it means that any applicable legal norms must be in accordance with the existing legal norms, and legal norms that are in a lower position if it conflicts with higher legal norms, then the norm must be canceled. Revocation of a norm of the statutory regulation is carried out with several alternatives. If the right of testing is given to the executive, then it is called an executive review, whereas if the right of testing is given to the legislature, it is called as a legislative review, and if the right of testing is given to the court, then it is called judicial review. ${ }^{9}$ Indonesia through the formulation in the constitution, in casu a quo, in chapter IX on judicial power of the 1945 Constitution of the Republic of Indonesia using the jucial review method, namely the right to test (toetsingrecht) is given to the judicial power institutions as regulated in Article 24 A Paragraph 1 and 24 C Paragraph 1 of the 1945 Constitution.

This is where problems arise in the Indonesian legal system, in this case about the mechanism of testing legislations which are not contrary to the law but they are contrary to the constitution. The problem is which court has the authority to try the norm

\footnotetext{
${ }^{8}$ Ahmad Redi, Hukum Pembentukan Peraturan Perundang-Undangan, (Jakarta, Sinar Grafika, 2018), p. 42.

9 Jimly Asshiddiqie, Hukum Acara Pengujian Undang-Undang Cetakan ke-2, (Jakarta, Sinar Grafika, 2012), p. 15.
} 
because it has not been regulated in the constitution or the law. If the test is submitted to the Supreme Court, it is clearly not possible because it refers to the provisions of Article 24 A Paragraph 1 of the 1945 Constitution of the Republic of Indonesia regulating that the Supreme Court only tests the statutory provisions under the law against the law. So here the test is the law. Whereas if this test is brought to the Constitutional Court, it is also not possible because based on the provisions of Article $24 \mathrm{C}$ Paragraph 1 of the 1945 Constitution of the Republic of Indonesia, the authority possessed by the Constitutional Court is regulated in a limitative manner. In the a quo article, the authority of the Constitutional Court in an explicit manner only has the authority to hear judicial review of the constitution. So what is being tested here is the law, not the statutory regulations under the law.

Based on these problems, there is a legal vacuum (rechtsvacuum) in the system of testing the norms of legislation in Indonesia, even though in a practical level, it is not impossible that the material contained in the statutory provisions under these laws contradicts the constitution although theoretically that each legal norm is always in harmony with the legal norms that are above it. By not regulating the mechanism for testing the statutory provisions under laws that contradict the aforementioned constitution, it may result in violation of the constitutional rights of citizens through the content of the laws and regulations under those laws which are considered unconstitutional.

Seeing this problem, there is a solution that can be used as an alternative in the mechanism of testing the laws and regulations under the law that contradicts the constitution, namely by amending the judicial power article in the 1945 Constitution of the Republic of Indonesia and changing the judicial review system which has been separate from the Court. Supreme Court and the Constitutional Court. As it was previously known that the Supreme Court in the provisions of Article 24 A Paragraph 1 of the 1945 Constitution of the Republic of Indonesia is authorized to examine the statutory provisions under the law, and the Constitutional Court through the provisions of Article 24 C Paragraph 1 of the 1945 Constitution of the Republic of Indonesia only has the authority to test the constitution against the constitution. Through this 
amendment, it will use the one-stop judicial review model by delegating that authority to the Constitutional Court. This is based on at least three arguments: first, the Supreme Court as the court of justice and the Constitutional Court as the court of law; second, is the background of the establishment of the Constitutional Court as the guardian of constitution, and also the sole interpreter of constitution; ${ }^{10}$ third, the background of the establishment of the Constitutional Court as a protector of citizens' constitutional rights.

The first principle refers to the function of the Supreme Court which has the authority to hear concrete cases in certain areas of law and the Constitutional Court which has the main authority as examiners of norms. Therefore, in order to avoid overlapping of authority between these two highest judicial power actors, it is better if the authority function is clearly separated, which acts as court of justice and which acts as court of law. The second principle, namely as the guardian of constitution, and also the sole interpreter of constitution, refers to the function of the Constitutional Court as a guardian for the implementation of norms in the constitution. In casu a quo, the Constitutional Court is obliged to ensure that norms in the constitution are obeyed and implemented by the legal norms that are below it. Whereas the principle of the sole interpreter of constitution means that the Constitutional Court is an institution that is given legitimacy to interpret the constitution. ${ }^{11}$ This does not mean that other state institutions do not have the right to do the same thing, but it is only the interpretation through the Constitutional Court that the interpretation has legal power through its decision.

Whereas the function of the Constitutional Court as a protector of citizens' rights is the Constitutional Court through its authority to conduct judicial reviews to protect the human rights of citizens from the possibility of violation of their human rights by laws and regulations issued by the legislative and executive branches. The author is of the view that the testing of legislation under laws contrary to this constitution needs to be carried out based on two arguments: first, theoretically, the state of Indonesia is a state of law that adheres to constitutionalism so that every action or provision of

\footnotetext{
${ }^{10}$ Op. Cit, p. 225.

${ }^{11}$ Op. Cit, p. 234.
} 
legislation must limited by law and based on the constitution as the highest law; second, at the practical level, the institutionalization of this test as well as a tangible form of the concept of checks and balances among branches of state power.

\section{Conclusion}

Indonesia is a country based on law, and not based on mere power. The logical consequence of this provision is that everything in this country is governed by the provisions of the law and the law. As a country regulated by law, Indonesia also adheres to constitutionalism. This understanding is closely related to the state that is governed by law and makes the constitution as the highest law. As a country that places the constitution as the highest law, it carries a logical consequence that the constitution serves as the basis for the application of lower-level legal norms. Therefore theoretically, all legal norms should be aligned and tiered until they are based on the constitution. However, in practice, the mechanism for testing of laws and regulations has not been carried out comprehensively, in casu a quo, testing of laws and regulations under laws that do not conflict with laws but are contrary to the constitution.

In this matter, which court has not been authorized to adjudicate the judicial norm testing, if it is related to judicial authority in the constitution, in casu a quo, Article 24 A Paragraph 1 and 24 C Paragraph 1 of the 1945 Constitution of the Republic of Indonesia concerning the Supreme Court and the Constitutional Court. Referring to article $a$ quo, the Supreme Court only has the authority to review the statutory provisions under the law against the law, while the Constitutional Court only has the authority to examine the law against the constitution. The incomprehension of mechanisms for testing legal norms in Indonesia can result in violation of citizens constitutional rights to the provisions of unconstitutional laws and regulations, whereas these constitutional rights can only be optimally enforced if a comprehensive mechanism for testing of laws and regulations has been realized.

Seeing this problem, there is a solution that can be used as an alternative in the mechanism of testing the laws and regulations under the law that contradicts the constitution, namely by amending the judicial power article in the 1945 Constitution of 
the Republic of Indonesia and changing the judicial review system which has been separate from the Court. Supreme Court and the Constitutional Court. As it is known beforehand that the Supreme Court in the provisions of Article 24 A Paragraph 1 of the 1945 Constitution of the Republic of Indonesia is authorized to test the statutory provisions under the law, and the Constitutional Court through the provisions of Article 24 C Paragraph 1 of the 1945 Constitution of the Republic of Indonesia only has the authority to test the constitution against the constitution.

The solution that can be used as an alternative is through amending the constitution regarding judicial authority. Through this amendment, the legal system testing system will later use the one-stop judicial review model by delegating that authority to the Constitutional Court. This is based on at least three arguments: first, the Supreme Court as the court of justice and the Constitutional Court as the court of law; second, is the background of the establishment of the Constitutional Court as the guardian of constitution, and also the sole interpreter of constitution; third, the background of the establishment of the Constitutional Court as a protector of citizens' constitutional rights. With the institutionalization of the a quo legislative testing mechanism, Indonesia as a state of law can at least minimize the possibility of violating the constitutional rights of citizens from the provisions of unconstitutional legislations.

\section{Bibliography}

Al Arif, M. Yassin, 2012, "Aktualisasi Paham Konstitusionalisme dalam Konstitusi Pasca Amandemen Undang Undang Dasar 1945”, Jurnal Pandecta, Vol. 12 No. 2.

Manan, B. dan Dwi Harijanti, S., 2014, Memahami Konstitusi Makna dan Aktualisasi, cetakan ke-1, PT. RajaGrafindo Persada, Jakarta.

Sinaga, B dan Sinaga, S., "Syarat Partai Politik Peserta Pemilihan Umum yang Inkonstitusional”, Jurnal Masalah-Masalah Hukum, Jilid 48. No. 3 Juli 2019.

Palguna, I.D.G., 2013, Pengaduan Konstitusional (Constitutional Complaint) Upaya Hukum terhadap Pelanggaran Hak-Hak Konstitusional Warga Negara, Sinar Grafika, Jakarta.

Atmadja, I.D.G., 2009, Hukum Konstitusi Problematika Konstitusi Indonesia Sesudah Perubahan UUD 1945 Edisi Revisi, Setara Press, Malang. 
Administrative Law \& Governance Journal. Volume 2 Issue 1, March 2020 ISSN. 2621-2781 Online

Redi, Ahmad, 2018, Hukum Pembentukan Peraturan Perundang-Undangan, Sinar Grafika, Jakarta.

Asshiddiqie, J., 2012, Hukum Acara Pengujian Undang-Undang, Cetakan ke-2, Sinar Grafika, Jakarta.

The 1945 Constitution of the Republic of Indonesia. 